\section{La Révolution française}

Cahiers de l'Institut d'histoire de la Révolution française

$8 \mid 2015$

Entre la Révolution et l'Empire : une nouvelle politique dans l'océan Indien

\title{
Mahé and the Politics of Empire: Trade, Conquest, and Revolution on the Malabar Coast
}

\section{Gregory T. Mole}

\section{(2) OpenEdition \\ Journals}

Electronic version

URL: http://journals.openedition.org//rf/1294

DOI: $10.4000 /$ Irf. 1294

ISSN: 2105-2557

\section{Publisher}

IHMC - Institut d'histoire moderne et contemporaine (UMR 8066)

Printed version

Date of publication: 23 June 2015

Electronic reference

Gregory T. Mole, « Mahé and the Politics of Empire: Trade, Conquest, and Revolution on the Malabar Coast », La Révolution française [Online], 8 | 2015, Online since 24 June 2015, connection on 14 February 2020. URL : http://journals.openedition.org/Irf/1294 ; DOI : 10.4000/Irf.1294

This text was automatically generated on 14 February 2020

(c) La Révolution française 


\title{
Mahé and the Politics of Empire: Trade, Conquest, and Revolution on the Malabar Coast
}

\author{
Gregory T. Mole
}

\begin{abstract}
"Everyone in Paris, Lorient, and even Pondicherry told me that that little comptoir was nothing; that one would never achieve anything there ${ }^{1}$,
\end{abstract}

1 Such were the warnings conveyed to Pierre-Antoine Duprat in 1772. Freshly commissioned as a colonel in the French army, Duprat had received an unenviable assignment: he was to serve as governor of Mahé, a small French trading post - or comptoir - on the southwestern (Malabar) coast of India. Mahé was remote, poor, and vulnerable; a forgotten outpost in a forgotten corner of France's colonial empire. Administered first by the Compagnie des Indes (the French East India Company), and then directly by the crown after the Company's dissolution in 1769, the settlement often proved out of sync with France's other factory-towns in India. The town remained neutral, for example, when France and Britain formally declared war during the 1740s, dividing shares of the local pepper trade with its British rivals while conflict raged across the other comptoirs ${ }^{2}$. Isolation bred peculation and unrest. Reports of corruption within Mahé abounded, while contentious political conditions in the region surrounding the town limited its opportunities for growth. During his journey to India, Duprat heard the same opinion in every port: even the ablest administrator could not rescue the comptoir from its enduring state of mediocrity.

2 These claims resonate within the historiography of France's colonial empire, which has consistently consigned Mahé to the margins. The very conditions that seemed to have limited Mahé's development, however, offer valuable insight into the dynamics of power operating within France's Indian settlements in the final decades of the old Regime. This article analyzes the history of the comptoir over the course of the eighteenth century, ranging from Mahé's establishment in 1725 to its capture by the 
British during the French Revolution. The story of France's colonial activity on the subcontinent tends to be broken into distinct phases; scholars analyze the Company's changing commercial policies, French military operations in India, and the evolution of French revolutionary politics in the comptoirs as discrete historical developments ${ }^{3}$. Yet as I illustrate, Mahe exhibited remarkable continuity over the course of the eighteenth century - confounding these historiographical divisions. In the face of a shifting array of external pressures, the town's notables fixated on the same set of local concerns: the settlement's geographical vulnerability, isolation, and chronic lack of funding. Over the span of several decades and several different administrative regimes, they capitalized continually on developments outside the comptoir to address these recurring problems. When viewed from the perspective of an individual comptoir, France's colonial project looks less a cohesive enterprise undergirded by crown sovereignty than a fractured endeavor riddled with competing nodes of authority and instantiations of power. Mahé's history, in short, reminds us that even supposedly marginal colonial spaces imposed their own rhythms on the reigning ideologies of empire in the eighteenth century.

India's significance to France often went beyond immediate material and geo-political considerations. As Kate Marsh writes, the land became a "locus... for assessing French national interests" - looming large in the imagination of France's political economists, philosophes, military leaders, and crown ministers ${ }^{4}$. From the time of the Company's inception in 1664 by Louis XIV's famed finance minister, Jean-Baptiste Colbert, French maintained lofty expectations for its Indian colonies. The establishment of a vibrant Indian trade would facilitate the development of France's domestic economy, frustrate the designs of rival English and Dutch corporations, and extend royal authority beyond the Cape of Good Hope. Even after the company's dissolution, India continued to capture the attention of policy makers, who hoped to make the recovery of French territory on the subcontinent the centerpiece of France's colonial strategy after the Seven Years' War.

4 This article uses three case studies - each situated within a discrete period in the historiography of French India - to rethink Mahé's place within the political imagination of the old Regime. As it shows, the expectations of metropolitan policymakers were not simply imposed on the Indian factory-towns by crown ministers and Company directors in France. Over time, the comptoirs developed their own trading networks, territorial ambitions, and cultural identity. Susan Dawdy investigates such a process in her study of colonial New Orleans, using the concept of "rogue colonialism" to describe the flexible commercial and political strategies the city developed in its relative isolation from metropolitan regulation ${ }^{5}$. This model provides a useful reminder of the forces driving municipal developments in sites across France's colonial empire. As Mahé's case reveals, isolation not only facilitated the creation of new markets and identities, but also the growth of a self-serving political economy and political culture. The comptoir's inhabitants approached everything from the commercial mandates of the Company to the energies released by the Revolution according to their own internal logic - interpreting these developments to suit the immediate needs of the comptoir. For them, the logic of France's colonial enterprise was shaped according to fundamentally local concerns. 


\section{Private Trade and Public Interest}

5 Mahé lies on the southwestern coast of India, covering both banks of a winding river (the Mahé) before it spills out into the Arabian Sea. Coconut palms blanket the town, which is dominated by a range of hills radiating out from the coast ${ }^{6}$. Contemporary accounts lauded the settlement's beauty, salubrious climate, and commercial prospects. Simon de la Farelle, a French officer who served in the campaign to seize Mahé, described the town's weather as the "healthiest and most temperate in India ${ }^{7}$." He also noted the abundance of grapes, cardamom, betel, and pepper that grew along the Malabar Coast. In both agricultural and aesthetic terms, Mahé seemed ideally located. While the hills surrounding the town offered stunning vistas, its fertile coastal plains supplied a wealth of valuable trading commodities.

6 If the town's topography created an appealing panorama, however, it also generated a daunting set of challenges. A sand bar blocked the mouth of the Mahé River, hindering the construction of harbor facilities, and a particularly severe monsoon season closed the settlement's port for months. The hills surrounding Mahé left it vulnerable to attack, requiring heavy outlays for defense. With a garrison of 120 French soldiers, 150 sepoys, and 30 cannon, the comptoir's military expenditures rivaled that of the much larger French settlement at Pondichéry ${ }^{8}$. Aggressive enemies lurked all around: both the English at the nearby settlement of Tellicherry and regional potentates along the Malabar Coast frequently challenged French interests in the area. Even with its outsized military budget, Mahé remained precariously placed. The French maintained a small subordinate factory within the nearby kingdom of Calicut - a trading station that rarely held more than a single employee' ${ }^{9}$. Otherwise, Mahé was isolated from the other French outposts in India. These geographical, logistical, and political impediments stunted the growth of the settlement; excepting a few periods of temporary expansion, Mahé rarely exceeded 200 hectacres (roughly two square kilometers) in area ${ }^{10}$.

7 The settlement was ruled jointly by a governor and a three-man assembly known as the conseil provincial, which was responsible for the town's administration, commerce, police, and court system ${ }^{11}$. Company merchants staffed the council positions, and were appointed to office by the existing councilors. In theory, this arrangement reinforced the hierarchical model of Company rule: while responsible for local affairs, Mahé's councilors were subordinate to the larger conseil supérieur in Pondichéry, as well as the overarching authority of the corporate directorate in Paris. The councils, moreover, contained a clear chain of command - with the rank of each councilor based on seniority. The town's employees were similarly regimented, divided broadly between commercial and military professions ${ }^{12}$. In practice, however, this political system cohered little with such a rigid conception of colonial authority. The council's small size, for instance, militated against the creation of a clear ranking system. Mahé collaborated with, more than deferred to, its neighboring colonial councils; its leaders exercised authority through informal networks of power built on patronage and kinship, and adopted a flexible strategy of negotiation and coalition building with local European and indigenous powers. As with many colonial governments in Asia, the settlement's council was amphibious in nature, varying between modes of obedience and open defiance to superior authorities, and alternatively defining itself as a merchant body and as an autonomous political entity ${ }^{13}$. 
Consider the way town officials addressed problems of local governance through the broader commercial ideology of the Company. Due to its size and location, Mahé was subject to a constant strain, torn between alluring prospects for trade and the material realities that constrained them. When the French established the comptoir in 1721, pepper was in high demand both in Europe and along regional trading circuits in the India Ocean. Indeed, the price of this commodity rose by $50 \%$ between 1722 and $1739^{14}$. The Company required Mahé's employees to meet an annual quota for pepper, as well as other regional commodities. Yet the settlement's heavy infrastructure costs depleted the funds set aside by the Company for these purchases. As one specialist notes, "it was money, always money" that proved the limiting factor in Mahé's commercial growth ${ }^{15}$. The constant lack of funding forced town administrators to rely on independent French traders operating along the Malabar Coast to develop Company commerce in the region. These merchants bought surplus pepper from the cash-strapped Company merchants to sell within local markets. Necessity thus created the conditions for a thriving private trade-one in which Company employees, who faced a shifting set of prohibitions against independent commercial activity, often engaged.

There was a constant demand for pepper in the markets surrounding Mahé. French merchants called on ports in the Arabian Sea and Persian Gulf, as well as along India's eastern (Coromandel) coast, and supplemented their local stocks by importing pepper from China ${ }^{16}$. This "country" trade, so-called because it concentrated on markets in India and the Indian Ocean rather than on the export of goods to France, often yielded excellent returns, helping to offset the comptoir's chronic lack of specie. Yearly funds sent from France to Mahé often arrived late - or sometimes not at all. The large profits generated by the "country" trade, by contrast, could be used immediately to purchase more pepper. Policymakers in Paris weighed the benefits of this commercial activity with the various challenges it created - struggling, in the process, to adopt a consistent position. After all, the demands of these local trading networks were almost always in tension with the Company's broader commercial agenda. "Country" trade facilitated the development of Mahé's pepper industry, but it also diverted commodities earmarked for France to more lucrative regional markets.

10 The development of private trade along the Malabar Coast thus spurred conflict between administrators in Paris and Pondichéry and employees in Mahé. Take the 1739 Mahé pepper scandal, a contentious affair whose origins lay in the fraught circumstances behind the comptoir's establishment. In 1721, Company representatives in Calicut signed an agreement with the Bayanour of Bargaret, ruler of the small princely state of Kadattanad, permitting them to settle at Mahé. The machinations of Robert Adam, the British governor of Tellicherry, however, delayed Company attempts to settle in the region. Eager to prevent French encroachment on the Malabar pepper trade, Adam incited a conflict in Kadattanad, attacked Company outposts around Mahé, and pushed the Bayanour to abrogate his agreement. A French squadron led by Bertrand-François Mahé de la Bourdonnais, who was to become one of the Company's most famous employees, eventually relieved the settlement with a force of 250 soldiers and 100 sailors in $1725^{17}$. The damage to the town, though, had been done. Military action secured the Company's claim to Mahé, and earned La Bourdonnais a celebrated nickname (the "Mahé" in his title). But the years of conflict frustrated French trading efforts in the region, and saddled the settlement with a considerable debt. Nearly 
insolvent, town officials commissioned private merchants to buy pepper on the Company's behalf. Thus began the comptoir's dependence on private trade.

By the 1730s, Mahé finally had enough money to purchase pepper on its own. Yet the town's addiction to private capital did not abate. Now, instead of buying pepper from private traders, Company officials began to sell surplus quantities to these merchants at an $8 \%$ surcharge, investing the profits in the town's infrastructure. Private societies such as Bonaventure Louet's Société de Mahé flourished throughout the decade, exploiting the high local demand for pepper - and their easy access to discounted sources of the commodity - to expand their role in the "country" trade. Even with its mark-up, the Company's prices for these middlemen were roughly $15 \%$ cheaper than those of the open market ${ }^{18}$. Private traders thus eagerly purchased Mahé's surplus quantities of pepper.

Initially, this arrangement seemed to meet the needs of all the parties involved. The Company received regular infusions of specie, while private merchants gained cheap and easy access to the region's pepper ${ }^{19}$. Such a compromise, however, would prove untenable in the long run. The division between private and Company commerce, unclear in the best of circumstances, became particularly muddled in Mahé as many of its councilors and employees began investing in societies such as Louet's. As more members of the Company became involved in private trade, the comptoir stopped meeting its pepper quotas - all this despite the fact that independent merchants operating out of Mahé continued sending private expeditions to Mocha, Basra, and China during the same period ${ }^{20}$.

Over time, the conseil supérieur in Pondichéry grew suspicious of the commitment of the comptoir's employees to the Company's trading interests, blaming "the poor administration of [Mahé's] council" for the years of diminishing pepper returns ${ }^{21}$. Tensions came to a head in April 1739, when several key figures in the comptoir's administration - Bunel, who served as a councilor, as well as Louet and another employee, Saint-Martin - replaced a ship transporting private freight to the port of Mocha, L'Heureux, with a Company vessel, La Marie Joseph, which was carrying "equipment" to the French outpost at Pegu in Persia. While initially perplexed over why Bunel and his accomplices had switched the ships, the conseil supérieur quickly guessed the reason: whereas La Marie Joseph was in "good condition" and "well crewed," L'Heureux was "leaky," and its sailors "completely exhausted" after a fifteen-month voyage $^{22}$. Bunel and his associates ensured the safety of their goods by placing them in the most seaworthy vessel available in Mahé. They had openly neglected their obligations to the Company in favor of private enterprise, seemingly confirming the conseil superieur's fear that officials in Mahé had been reselling Company pepper through the city's private societies.

The councilors in Pondichéry responded to these transgressions by dismissing all three members of Mahé's administrative council and placing Bunel, Louet, and Saint-Martin under house arrest in mid-April. Not all of the councilors, however, accepted their punishment gracefully. Bunel fled his home on the night of the sixteenth or seventeenth, "leaving no trace by sea or land." Suspicions of complicity immediately fell on his erstwhile accomplice, Louet, who lived so close next door that "it seemed impossible that" he or "several of his servants could not have seen his movements by the light of the moon ${ }^{23}$." It was not until 3 May that Bunel was found hiding in the house of a Company gunner, where he was promptly rearrested and taken to the fort of 
Mahé $^{24}$. He would eventually be recalled to France. Louet would return to Europe to plead his case as well. Better connected employees like George Duval de Leyrit, the future governor of Pondichéry, were quickly forgiven of any crimes and allowed to return to Mahé25. As was frequently the case in Company courts, sentencing varied according to the degree of influence that an employee commanded.

While the Company proved selective in its punishment of the individuals involved, its reaction to the Mahé affair itself was unwaveringly severe. The directors in Paris used the incident as an excuse to launch into a general denunciation of private commerce. In their correspondence with Pondichéry, they called officials on the conseil superieur "equally reprehensible [as the employees in Mahé] for knowing of similar incidences and not reporting them to the Company ${ }^{26}$." Having long protested against violations of Company trading policies by employees overseas, the Paris directors were quick to use the scandal as a pretext for denouncing the corruption, abuse, and "low regard for the interests of the Company" that seemed to characterize French commercial activity throughout India ${ }^{27}$.

If this stern rebuke had been the end of the affair, the 1739 scandal would merely represent one sensationalized example in a long line of disagreements over the unsanctioned trading ambitions of Company employees. The pepper crisis, though, continued to inspire contentious debate for several decades. While the directors seethed and the councilors in Pondichéry demurred, Company employees took it upon themselves to judge the implications of Mahé scandal. Jacques d'Eprémesnil - the onetime head of the Company's council in Madras after the French conquest of the city - offered perhaps the most vocal reaction to the affair in his 1755, Sur le Crédit de la Nation dans l'Inde, where he lamented the long-term consequences of the Company's reaction to the incident. The Company's directors, he argued, failed to calibrate their trading policies according to the diverse political and economic circumstances within each of the comptoirs ${ }^{28}$.

The incident in Mahé turned from an extreme and public case of abuse by colonial officials to a more general indictment of arbitrary regulation and the Company's limited commercial vision. According to d'Eprémesnil, the directors' response introduced the disastrous notion "that the Company would look with disfavor on all employees who enriched themselves by legitimate means ${ }^{29}$." In Pondichéry, members of the council used the circumstances surrounding the affair as evidence that the Paris directors knew little about the actual practice of trade. While continuing to blame employees in Mahé for neglecting their duties in the pursuit of "private interests", officials in Pondichéry blasted the Company for imposing heavy duties on goods entering the Malabar Coast, which prevented ships from Basra, China, and Macao from selling their wares in the French port ${ }^{30}$. According to the council, unjust Company prohibitions had pushed the employees in Mahé down a destructive path by impeding the commercial development of the comptoir ${ }^{31}$.

D'Eprémesnil elaborated on this claim in his 1755 treatise. Like the Pondichéry councilors, he argued that the Mahé scandal was symptomatic of a more general problem: the failure of Company directors to understand market conditions on the subcontinent. Administrators in Paris grumbled about the Company's lack of profitability while at the same time condemning men like Louet, who in his "long stay at Mahé had acquired a perfect knowledge of the language, customs and commerce of

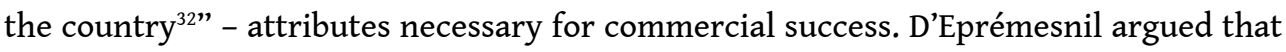


the development of a robust private trade was the most assured way of acquiring credit among indigenous lenders in the French-occupied regions of the subcontinent ${ }^{33}$. He saw in the Mahé affair a perfect example of how the Company mismanaged its affairs. Company directors ignored the pleas of employees in India while allowing misplaced suspicion, imperfect understandings of commercial science, and political circumstances in France to dictate their trading policies.

To be sure, d'Eprémesnil's account overlooked key details about the Mahé affair, including the seemingly clear complicity of Bunel, Louet, and Saint-Martin in defrauding the Company. There were good reasons for such an omission. D'Eprémensil had begun his career in India as a private trader, and his brother, Georges de Leyrit, was heavily implicated in the pepper scandal. The entire focus of d'Eprémesnil's essay was on the failure of the Company's efforts to support credit-acquiring ventures in India, and his emphasis on the economic fallout from the pepper crisis strengthened his overarching claims. Nonetheless, d'Eprémesnil's interpretation of this incident highlights a problem that had become obvious to employees early in the Company's trading operations in India. The issue of "country" trade represented a significant stumbling block in relations between those undertaking commerce in India and those regulating it in France. What on the one side constituted innovative commercial practices seemed to the other like self-interested abuse. These divergent perspectives reflected a fundamental disagreement within the Company over the compatibility of profit seeking and private enterprise with the obligations of public service.

In the contentious correspondence between the Company and its colonial councils, in ship manifests that disguised the illicit commercial activities of Company employees, and in rancorous mémoires that inveighed against Company policy, an ongoing contest over private trade played itself out. Throughout the 1720 s and 1730 s, the Paris directors constantly adjusted their stance on this issue; "nothing," argued Alfred Martineau, "was more capricious" than the Company's approach to "country" commerce $^{34}$. This dispute touched on commercial activities in all of the comptoirs; but tensions were most pronounced over the pepper trade centered in Mahé. No other commodity created such a pronounced strain between the Company's trading agenda and the commercial interests of private traders. The style of textile demanded by wholesalers in Europe differed from those that were popular in the markets of India; in the case of this trade, there was little overlap between the goods sold by the Company and those distributed by independent merchants. Pepper, though, fetched a high price both in France and in ports across Asia $^{35}$.

The very factors that limited Mahé's development caused the comptoir to loom large in the ongoing contest over the Company's monopolistic trading policies. Spurred by their financial distress, isolation, and strategic vulnerability, the councilors of Mahé intermingled with the private trading societies that had sprung up throughout the settlement, precariously balancing their duties to the Company with their commitments to these competing commercial interests. As d'Eprémesnil's treatise attests, the controversies generated by this muddled situation continued to inspire vocal debate years after the 1739 scandal shattered this arrangement. Unfolding along lines of patronage and across family networks, these conflicts confounded simple distinctions between metropole and colony, or licit and illicit commerce. They represented an attempt by Mahé's governing council and chief employees to situate, 
and ultimately to resolve, problems immediate to their settlement within the broader political economy of the Company.

\section{Expansion and Diplomacy}

Beginning in the 1740s, the Company found itself embroiled in an almost unending series of violent conflicts. With the War of the Austrian Succession raging in Europe, the British and French along the Coromandel Coast. When peace was secured in the 1748 Treaty of Aix-la-Chapelle, colonial administrators from both nations replaced open fighting with backroom dealing - supporting rival claimants to several local kingdoms in the hopes of increasing their influence and creating new sources of revenue. These indirect methods of expansion, often pursued without the knowledge of superiors in Europe, led once again to open conflict in the early 1750s. Despite some initial success, the French Company soon experienced a series of reverses. In 1754, the architect of these controversial proxy wars, Joseph Dupleix, was recalled to Paris to answer for his actions ${ }^{36}$. While peace was briefly achieved from 1754 to 1755 , the outbreak of the Seven Years' War resulted in the eruption of a new set of conflicts on the subcontinent - all with disastrous results for the French. By the end of the fighting in 1763 , the Company had lost all its chief comptoirs, as well as many of its subordinate factories.

Before this conflict-ridden period, Company employees chafed under restrictive trading regulations. As violence unfolded across India, however, problems of geopolitics and military strategy emerged as a new source of contention. In their correspondence with Paris, in rancorous colonial assembly meetings throughout the comptoirs, and in negotiations with their local allies, employees openly questioned the Company's purpose in India. They debated whether a corporation chartered to oversee foreign trade could also govern large swathes of foreign territory, and wondered about the rights of colonial officials to expand Company holdings without consulting authorities in France. Given greater publicity by the efforts of Dupleix, who appealed to the public in a series of tendentious mémoires after returning to France ${ }^{37}$, these questions inspired a broader criticism of Company activities as years of unremitting conflict crippled French interests in India.

24 Such critiques acquired a new intensity as the Company collapsed under the pressure of debt and public censure after the Seven Years' War. During the late 1760s, the Company's impending dissolution sparked a vicious series of conflicts over free trade, the economic health of the nation, and the moral implications of overseas commerce. Satirical poems "eulogized" the death of the Company in Paris, while Company investors squared off against crown ministers and the economic theorists of the Gournay Circle, a prominent set of free trade advocates ${ }^{38}$. Often forgotten in the din of these disputes over commercial policy and economic interest were the pressing strategic concerns created by France's defeat in the Seven Years' War. When the Company fell in 1769 , the crown assumed direct control of the comptoirs. Following this development, activity in India would be judged according to how well it served the monarchy's foreign policy rather than by the profits it generated.

Initially, Mahé contributed little to this growing anxiety over diplomacy and strategy. The comptoir engaged in a brief conflict against the Bayanour of Bargaret from 1740-1741, but this war had few of the controversial implications of the violent fighting 
that raged through Bengal and eastern India from the 1740s to the early 1760s. Despite the comptoir's best efforts to maintain a peaceful settlement along the Malabar Coast, however, broader developments in the Seven Years' War conspired to frustrate this plan. After a decisive French defeat at the 1757 Battle of Wandiwash, the British began systematically subjugating France's settlements in India. By 1761, Britain had captured Chandernagor in Bengal, the Company's most profitable comptoir, and seized Pondichéry after a siege lasting several months. Mahé succumbed soon after, surrendering on 8 February 1761.

Although Mahé had remained fairly removed from the divisive disputes of the previous twenty years, questions about how the town fit within the broader patterns of French strategy in India after the Seven Years' War quickly became a source of contention. Negotiations with the British for the return of the comptoir went through frequent delays, stalling over questions of restitution and the borders of the settlement. The British destroyed a number of houses, fortifications, and warehouses in Mahé, while the Kattanad ruler, to whom they then ceded the comptoir, plundered what remained of the settlement. Louis Plusquellec, a French army captain assigned to treat with the British, insisted on three lakhs (300,000 rupees) in compensation for these depredations, but his demands fell on deaf ears ${ }^{39}$. In their correspondence with their superiors in Pondichéry, the Mahé councilors complained constantly about the "bad faith" of the British, who seemed to care little about the terms of the French capitulation ${ }^{40}$. They worried as well about the French relationship with the various feudatories surrounding Mahé, complaining that the princes in the region "treated them arrogantly" and expressing skepticism about the continued viability of the French settlement ${ }^{41}$.

On 20 October 1765, the French finally agreed to a settlement that reduced Mahé to its 1749 borders. The comptoir's future, though, still remained in doubt. Picot de la Motte, Mahé's governor, wrote of his "embarrassment" at assuming the command of a town "without money" and "without any resources"." In a 1767 mémoire discussing conditions within the European settlements across India, Jean Law de Lauriston - the new governor of Pondichéry - contrasted the "immense sums" required for the upkeep of the comptoirs with the "little trade" undertaken there. He suggested that the French resettle to either Collèche, on the southern tip of the subcontinent, or Karwar, located near the Portuguese colony of $\mathrm{Goa}^{43}$. Even after the British restored the comptoir to France, Mahé's place among the other French settlements in India remained unclear.

Part of this confusion stemmed from the uncertain vision of crown policymakers regarding French interests on the subcontinent. Historians remain divided over France's intentions in the aftermath of the Seven Years' War. Whereas some scholars contend that the French abandoned their grander designs in India after 1763 contenting themselves instead with the maintenance of a few small commercial settlements - others argue that France's colonial administrators were committed to expanding as soon as it was practicable ${ }^{44}$. Whatever the case, French designs often seem to have been highly improvised. Instead of following a consistent trajectory, plans shifted to fit within an ever-changing geo-political climate and to conform to the personal projects of various crown officials. India loomed large in the revanche, or vengeance-oriented, schemes of foreign ministers like the Duc de Choiseul and the Comte de Vergennes, who sought to limit the growth of the British territorial holdings overseas. But French policymakers were reluctant to engage in a concerted program of 
imperial expansion on the subcontinent. Instead, France adopted an opportunistic approach to developments in India; unwilling to invest the manpower and funding needed to mount a serious challenge to Britain's interests in India, they exploited local alliances in the hopes of halting British expansion ${ }^{45}$.

Mahé played a prominent role in this indirect strategy. The settlement lay near the Kingdom of Mysore, a powerful state whose leader, Haidar Ali, opposed British expansion in the southern regions of the subcontinent. Haidar Ali had deep ties with France. During the succession crises in Hyderabad and Arcot, he had served alongside the Company as commander of Mysore's cavalry. By 1760, Haidar Ali had deposed the reigning Hindu ruler of Mysore, converted the kingdom to Islam, and introduced a set of modernizing reforms. He established a new capital at Seringapatam, where he built an imposing citadel, and hired European engineers, soldiers, and advisors to create a potent field army. Eager to benefit from these improvements, French policymakers courted Haidar Ali aggressively in the aftermath of the Seven Years' War. The Duc de Choiseul dispatched a delegation to his court in 1769, and Law de Lauriston maintained regular contact with the reform-minded king ${ }^{46}$. But it was with the councilors at Mahé that Haidar Ali had the most regular contact.

Administrators in the comptoir corresponded with the king on behalf of their superiors in Pondichéry, but they also used their relationship with Haidar Ali to try and improve Mahé's situation on the Malabar Coast. When the ruler of Kattanad squeezed onerous concessions from the French in exchange for the return of the town in 1765, Mahé's councilors considered appealing to Mysore to intervene on their behalf ${ }^{47}$. A year later, Picot wrote to Law de Lauriston about his hopes that Haidar Ali, who had been campaigning in the territory around Mahé, would restore the settlement to its post-1749 borders ${ }^{48}$. In Versailles, the architects of French foreign policy hoped to exploit an alliance with Mysore to challenge British expansion throughout in India. The councilors of Mahé, however, approached this potential diplomatic relationship by considering its more immediate implications for the comptoir.

Despite these hopeful entreaties, Haidar Ali made for an uncertain ally. At the same time as Mahé's leaders attempted to exploit the king's expansionist policies to increase the revenues, borders, and regional status of the comptoir, they remained unclear about his intentions. In an anxious January 1766 memorandum, the settlement's council reported to Pondichéry about the appearance of a Mysore fleet along the Malabar Coast, noting with concern that "they still did not know what footing they were on" with Haidar $\mathrm{Ali}^{49}$. A few months later, the councilors reported that the king, who had by this point conquered many of the territories adjacent to Mahé, was interfering with the comptoir's pepper shipment ${ }^{50}$. Even as he opposed British interests in India, Haidar Ali entertained envoys from Tellicherry, who lavished the king with gifts that the delegates from Mahé could not afford to match. A partnership between Britain and Mysore never materialized, but the possibility of reduced tensions or even an actual alliance between the two rivals seemed real enough in the $1760 \mathrm{~s}^{51}$. Thus while authorities in Pondichéry and Paris attempted to cultivate Haidar Ali, Mahé experienced firsthand both the threats and tantalizing possibilities of diplomatic ties with Mysore. The comptoir's authorities attempted to use this relationship to restore the settlement to regional significance, but found themselves just as likely to suffer from the expansionist policies of Haidar Ali as to benefit from them. 

set of directives from his superiors, and a colonial official with local political obligations and considerable latitude in the handling of municipal affairs. Mahé's most pressing issue in the early stages of Duprat's tenure was a financial; by 1773, the comptoir could not even meet basic operating costs ${ }^{54}$. Duprat's overriding goal was thus to restore economic stability to the settlement. To do so, he proposed an expansionist campaign redolent of the aggressive policies of Dupleix. Whereas Duprat's project had all the controversial implications of this earlier scheme, though, it contained little of its careful consideration of geo-political conditions on the subcontinent. Consider Duprat's description of this plan in his later memoirs: "I was convinced that good faith would do more than gold...going from that principle, I came upon the notion to create an empire for France ${ }^{55}$." Confident that ambition and French élan would carry the day even in the face of a crippling lack of manpower, funding, and materiel, Duprat searched for convenient opportunity to extend Mahé's influence.

colonel soon found such an occasion in a local conflict between the nearby kingdom of Calicut - where the French maintained their small trading post - and Mysore. Calicut had been a tributary of Haidar Ali's since his expansion along the Malabar Coast during the late 1760s. Sensing that Mysore was overextended, however, the Zamorin of Calicut, the territory's ruler, reinstalled himself and declared his kingdom independent in 1773. He then petitioned the French for aid. Duprat recast Mahé's relationship with Haidar Ali to justify his intervention in Calicut. In a mémoire written to explain the campaign, he wrote: "this conqueror, they say, is our friend: but I know instead that it is us who have made him so ${ }^{56}$." Duprat listed the concessions France had made to the king of Mysore, noting that even though France had accommodated all of Haidar Ali's demands, it still did not enjoy a meaningful partnership with him. According to Duprat, Haidar Ali was a false friend, someone who proclaimed his desire for an alliance, but then "who acted like an enemy" by 
subjugating the territories of France's allies ${ }^{57}$. Ostensibly acting on behalf of Calicut, the colonel planned to turn Mahé into a center of regional power. He entered into terms with the Zamorin without consulting his superiors in either Pondichéry or Paris.

The results of this ill-considered venture were predictably disastrous. After concluding a treaty with the Zamorin, Duprat set sail for Calicut with a force of 150 soldiers and three cannons ${ }^{58}$. He arrived to find a Mysore fleet blocking Calicut's harbor. While Duprat obsessed over fanfare - delaying the disembarkation of his troops so that they could "descend with all possible glory" in the light of day - Haidar Ali dispatched his trusted general, Srinivasa Rao, with tens of thousands of troops to retake Calicut ${ }^{59}$. The soldiers from Mahé soon found themselves surrounded, forcing Duprat to reconcile his deeply held beliefs about the superiority of French spirit with the fact that he was vastly outnumbered. The Zamorin soon fled Calicut, and Srinvasa Rao permitted Duprat to abandon his position. Humiliated but alive, Duprat returned to Mahé at the end of January 1774. His campaign had lasted a little longer than two weeks.

The colonel's actions immediately following this incident further undermined French relations with Mysore. Still stinging from his defeat, Duprat declared in March 1774 that he would enforce France's exclusive right to the pepper trade in the area immediately surrounding Mahé. The comptoir had enjoyed this monopoly since the 1720 s, but the settlement's council rarely exercised its trading privilege. With too little money to purchase all of the pepper set aside for them by the ruler of Kadattanad, the French traditionally allowed this prince to sell off surplus amounts of the spice. In quick succession, Duprat cancelled this arrangement - a ruinous turn for Kadattanad since Mahé still could not buy up all the region's pepper - and commanded Haidar Ali to make all his future purchases of the commodity from the French ${ }^{60}$. These maneuvers once again brought France to the brink of war with Mysore. Only the direct intervention of Law de Lauriston, who dismissed Duprat, countermanded his demands to Haidar Ali, and reappointed Picot de la Motte, prevented the breakout of hostilities.

Short-lived as it was, Duprat's expedition had serious long-term consequences. The colonel's rash actions poisoned French relations with Haidar Ali. During the course of the campaign, Duprat had drafted a string of imperious letters to the king, threatening Mysore and admonishing Haidar Ali to avoid interfering with French interests. Even in defeat, he continued to antagonize the king; after his capitulation in Calicut, Duprat wrote haughtily to Haidar Ali that he had withdrawn on his own initiative, not out of fear of Mysore ${ }^{61}$. Certainly the colonel's dismissal helped reduce tensions, as did the return of Picot and his more diplomatic style of governance in 1775. But relations remained strained in the period immediately following Duprat's administration. Haidar Ali would remain distrustful of the French in general - cooling not only toward the councilors at Mahé, but also Law de Lauriston. Rumors of Mysore's disaffection inspired new intrigue among the British, who encouraged a local ruler, the Prince of Chirakkal, to expand at Mahé's expense. The French halted this aggressive maneuvering through several skirmishes fought along Mahé's borders ${ }^{62}$. But several years would pass before Haidar Ali seriously considered French entreaties again.

Historians often forget Mahé's impact on French military and diplomatic developments on the subcontinent, fixating on events along the Coromandel Coast and in Bengal while overlooking significant developments within the comptoir ${ }^{63}$. Yet Mahé's efforts during this period of contentious campaigning and hesitant policymaking offer an instructive reminder of the divisive impulses operating across France's Indian 
settlements. As administrators in Pondichéry and Paris hope to advance French fortunes through opportunistic alliances and proxy campaigning, councilors in Mahé exploited this strategy in an attempt to transform the comptoir into a regional power. French officials on the Malabar Coast petitioned Mysore to redress a string of grievances, from the unequal distribution of the pepper trade to the aggressive policies of the British at Tellicherry. As in the case of Duprat and his costly adventure, these efforts could diverge sharply from the general French strategy pursued in India. Even as France's grip on India continued to loosen, the ambitions of Mahé's councilors proved resilient, and their pursuit of local interests aggressive.

Larger developments, however, would conspire to frustrate these aims. In 1778, France declared war on the British as part of their effort to the support the American Revolution. Although this aggressive posturing contributed to Britain's defeat in North America, it left the French comptoirs in India once more vulnerable to attack. Pondichéry fell in October of that year. Picot de la Motte appealed to Haidar Ali for help defending Mahé - delaying a British assault through his entreaties. Once it became apparent that Mysore would not intercede directly on the comptoir's behalf, however, British soldiers finally moved against Mahé, which by early 1779 was the only remaining French settlement in India. Isolated, undermanned, and without hope of outside assistance, Mahé surrendered in March. Positioned precariously between Tellicherry and Mysore, the settlement would remain a contested site for the duration of the war. Although he had refused to intercede on Mahé's behalf, Haidar Ali soon found himself at war with Britain, and the comptoir would trade hands several times during the conflict. British troops once more pillaged the settlement; by the time hostilities between Britain and France ceased in 1783, the town was in ruins.

\section{Restoration and Revolution}

On 1 March 1789, commissioners for the Compagnie des Indes, which had been reconstituted in 1785 , wrote enthusiastically to administrators in Pondichéry about a series of radical developments in France. The kingdom was beset by a financial crisis, teetering on the brink of "a general bankruptcy ${ }^{64}$." But while this situation should have been a cause for alarm, it had instead become a source of celebration. In the throes of fiscal desperation, Louis XVI had restored Jacques Necker - the Genevan banker who served as Controller-General from 1776-1781 - to his former position. The reappointment of the celebrated minister, who had garnered popular acclaim by pushing for greater transparency in the management of royal finances, generated excitement across France. The report noted the "joy spreading in the hearts" of the people, the "euphoria" in Paris and the "enthusiasm" that seemed to "burst" across the provinces $^{65}$. The commissioners themselves admitted that they could barely "restrain their rapture ${ }^{66}$." Necker had always supported Company activities; as a former shareholder, he had vocally defended the corporation during its dissolution in $1769^{67}$. Rather than generate a sense of foreboding, the economic catastrophes preceding the Revolution created a sense of new opportunity for France's long-neglected comptoirs in India.

Indeed, such a change was welcome in Mahé, where there had been little cause for optimism in the years between the American and French Revolutions. During this period, the French balanced increasingly unrealistic hopes of expansion with the threat 
of complete collapse. A fleet under the command of Admiral de Suffren challenged the British in the Indian Ocean, while the French agent Montigny labored for several years to establish a partnership between France and the Maratha Confederacy, a powerful collection of Hindu princes that controlled much of central India ${ }^{68}$. Yet the war also ravaged the French settlements, which were restored to France as part of the conditions of the 1783 Treaty of Paris, and ultimately did little to challenge Britain's interests on the subcontinent. When the French reassumed control of Mahé in 1785, few buildings remained undamaged. Once more, France's oversized ambitions confronted the material limitations and strategic vulnerability facing its comptoirs.

The reconstitution of the Compagnie des Indes by Charles Alexandre de Calonne, the finance minister who served immediately after Necker's first term as ControllerGeneral, offered institutional change with limited relief. The new Company floated a twenty thousand rupee loan to the settlement, which permitted the reconstruction of administrative offices, a magazine, a jail, and a church ${ }^{69}$. Eager to avoid provoking the British into future conflicts along the Coromandel Coast, policymakers in France even considered turning the comptoir into the chief French settlement in India. The geographical challenges that had constrained the town's growth, however, dissuaded the French against pursuing this plan ${ }^{70}$. Even with many of its important structures rebuilt, Mahé remained vulnerable to attack by local bandits; the garrison was undermanned, the border unfortified, and the harbor rarely visited by French warships. Unable to attract many investors, the Company lacked the additional funds needed to develop Mahé's military infrastructure ${ }^{71}$. De Canaple, the town's governor, captured the desperation of this situation in a September 1789 letter to his superior in Pondichéry: "For two years, I have witnessed the agony of this comptoir: spare me, I beg of you, from the sad spectacle of its death ${ }^{72}$."

The transition between new Company government and the early stages of the Revolution reveal a growing emphasis on centralization and standardization in all the Indian comptoirs. In 1784, a royal edict eliminated the former municipal administration system and replaced it with a more streamlined conseil, reinforcing crown control by placing the comptoir under the control of a royal commissioner, and apportioning offices based on seniority (all merchants over 25 were invited to serve on the council). The establishment of Calonne's company the following year further limited municipal autonomy; the corporation's charter defined it as an explicitly commercial enterprise, with no additional governmental privileges or obligations ${ }^{73}$. Revolutionary developments in France seemed to complement this emphasis on centralization. Fiscal reform, personnel shifts, and a more rationalized colonial policy followed the bloodshed, social breakdown, and political restructuring that characterized the early years of the Revolution ${ }^{74}$. Across France's empire, notions of liberty, citizenship, and representation framed a shared political vocabulary and culture.

Recent scholarship, however, has revealed important limits to the universalist aspirations of the Revolution within the French empire. While the National Assembly espoused a language of undifferentiated popular sovereignty, France's colonies remained subject to exclusive trading practices that favored metropolitan merchants ${ }^{75}$. The institution of slavery presented a nearly intractable paradox for revolutionary idealists, for chattel slaves were at once a type of possession protected by the Revolution's growing emphasis on individual property and a bonded people denied the liberty that was so central to its political culture ${ }^{76}$. And as in the metropole itself, 
revolutionary upheaval created new occasions for violence and social disorder. Mahé's experience reinforces this image of a Revolution based on difference, divided interests, and confused conceptions of authority.

In December 1790, the citizens of Mahé created a colonial assembly, replacing the settlement's administrative council with a new assembly composed of all Frenchmen in the colony, and establishing a national guard. The town's new governor, Le Tellier, struggled to manage these revolutionary developments. He described Mahé as a "ship", beset on all sides by a storm, "and called himself" a novice hand" managing "the helm at a time when an experienced man was needed ${ }^{77}$." In a series of missteps, Le Tellier delayed alerting Pondichéry about the creation of the colonial assembly until April $1791^{78}$. He also made a string of concessions to the legislature's new president, M. de Boyer. While Le Tellier maintained nominal authority, the colonial assembly assumed control over political, commercial, and military affairs in the comptoir.

From the beginning, Boyer devoted himself to addressing the comptoir's crumbling infrastructure and insufficient funding. A former purchasing agent for the Company, he exploited his wealth to consolidate power. As Le Tellier noted, Boyer distributed large sums of money throughout the impoverished comptoir ${ }^{79}$. The president adopted the manners of a revolutionary, strolling through Mahé in a "national costume" to which he appended ceremonial "epaulets," and employing the language of fraternal citizenship. But he devoted most of his attention - and nearly 5000 rupees - to reforming the administration of the hapless comptoir ${ }^{80}$. Through both political maneuvering and direct investment, Boyer facilitated the construction of a new town hall and the distribution of subsidized rice. Under him, Mahé's revolutionary energies manifested themselves in a series of material improvements. While he spoke and dressed like a patriot, Boyer seemed to show little concern for the course of the Revolution in either France or the other comptoirs.

The initial enthusiasm over these improvements quickly gave way to dissension and factionalism. In April 1791, the Company dispatched an agent from Pondichéry, de Gondreville, who tempered some of Boyer's most radical reforms. At de Gondreville's suggestion, Boyer gave up his presidential office - adopting the title of mayor in the spirit of greater equality - and restored Mahé's council to power ${ }^{81}$. But just as town revolutionaries approached a point of stability, personal conflicts between several notable citizens threatened to tear the new political settlement apart. In May, M. Menesse, the leader of Mahe's national guard, accused a follow conciliar, M. Dubreuilh, of slandering his name. In retribution for this supposed calumny, Menesse invoked his authority and attempted to remove Dubreuilh from the town council. As the string of accusations, recriminations, and reprisals spiraled out of control, Boyer convoked an emergency meeting of Mahé's council. Ever one for symbolic gestures, he came before this assembly carrying a small, ornamental case, from which he produced a red flag - a dramatic production, he explained, meant to signify the start of martial law. Boyer then arrested Menesse, condemning him for his demagoguery and tyrannical impulses. Instead of restoring calm, Boyer's handling of the affair created new divisions among the citizenry. By July, Le Tellier noted in alarm to the governor of Pondichéry that the town had descended into chaos ${ }^{82}$.

If the Revolution provided Mahés notables with an opportunity to improve conditions within the town, it also masked the pursuit of private agendas behind legitimate pretense - thus reinforcing the ambiguity that had marked the relationship of private 
interest to public policy throughout Mahé's history. Langlade, a town merchant who defended Menesse against Boyer's oppressive policies, captured this tension in an address delivered before the town's council. "Assemblies are made for the general good," he admonished the councilors, "not for personal affairs ${ }^{83}$." Judged an accomplice of Menesse's, Langlade was soon jailed as well. He escaped at the end of July and fled toward Travancore, a kingdom to the south of Mahé. Le Tellier did little to restrain the turmoil; the trial of Menesse would continue for months until he was eventually sent to Pondichéry for judgment by the conseil superieur. The town remained in an uproar until the arrival of Le Tellier's replacement - Larcher - in October 1791.

Larcher helped restore some stability to the comptoir. Despite his calming influence, however, the factionalism that had divided the town during the early phases of the Revolution soon created further tension. In May 1792, Pondichéry's colonial assembly found Menesse not guilty of the charges leveled against him. As compensation, the assembly ordered Boyer to pay him an indemnity of 6,300 rupees $^{84}$. This acquittal signaled a dramatic shift in political power within Mahé. Menesse soon returned to the comptoir, and with a mandate for municipal reform from Pondichéry, demanded that the Mahé council hold new elections through a general assembly composed of all the town's citizens. This call for legislative change spurred the rise of competing electoral factions - one under Boyer, and the other under Menesse and Langlade, who had also returned to the settlement. On 24 June, the general assembly elected a new central committee consisting of nine legislators. As recipients of the highest and second highest tally of votes, Menesse and Langlade became the de facto leaders of this new legislature. Boyer and his supporters, by contrast, were completely ousted from power ${ }^{85}$.

51 From political prisoners to municipal leaders in little less than a year, Menesse and Langlade set about consolidating their authority. They soon ran afoul of Larcher, however, who sought to limit their disruptive influence. Larcher refused to recognize the legislative changes enacted in late June, and demanded a new meeting of the town's general assembly in early July. At this gathering, he questioned the course of revolutionary developments in Mahé, denouncing the erroneous thinking and "reckless desire for absolute independence" that seemed to drive the town's citizenry ${ }^{86}$. In eloquent fashion, Larcher challenged the course of Mahé's entire revolution, which opposed local interests and antagonisms to the lofty aspirations for representative government, human rights, and universal brotherhood that supposedly infused the revolutionary movement in France. Larcher succeeded in convincing the assembly to reverse the summer's recent developments. But his politicking aroused the anger of town notables such as Menesse, Langlade, and even Boyer. As early as 9 July, Langlade sent a letter to Pondichéry complaining about Larcher's conduct ${ }^{87}$.

The governor in Pondichéry condemned Larcher for involving himself too intimately in the private affairs of the settlement. This censure inspired new intrigue on the part of Mahé's aggressive committee members, who continued to protest against Larcher's decisions over the following months. Not until October 1792, when the Pondichéry assembly decided to award Menesse and Langlade a settlement of 12,000 rupees, did tensions finally begin to relax $^{88}$. In a year of infighting and intrigue, Mahé's revolutionaries had done little to improve the town. As was the case in both France and within the colonies, the reformist energies of the early Revolution had given way to 
aggressive partisan politics. Although Larcher finally achieved stability in the comptoir, Mahé remained poor, underdeveloped, and vulnerable.

Indeed, regional diplomatic and strategic challenges continued to haunt the town. While officials in Pondichéry strove to create a national assembly composed of delegates from all the comptoirs, war between Britain and Tipu Sultan raged along the Malabar Coast. The son of Haidar Ali, and an occasional ally of the French, Tipu continually violated Mahé's borders during the conflict. The British, meanwhile, began to stop and search French shipping under the pretense of halting the flow of contraband to Mysore ${ }^{89}$. In the interim between the two crises involving Boyer and Menesse, Larcher busied himself by protesting against the violations of French neutrality. For the most part, however, his pleas went unanswered. Despite its initial promise, Mahé's revolution seemed to create more problems than solutions. Fearful of the revolutionary movement, Britain declared war against France in 1793, blockading the Atlantic coast and attacking French colonies in the Caribbean and Asia. For the third time in less than thirty years, British forces threatened Mahé. Realizing that the comptoir was indefensible, the town's general assembly decided to accept whatever the terms the British offered ${ }^{90}$. On 16 July 1793 , Mahé surrendered. Britain would not restore the settlement to France until after the Napoleonic Wars.

Mahé's citizens exploited revolutionary developments to assert the comptoir's autonomy, as well as to advance certain factions within the municipal government. This trend left the settlement not only divided internally, but also susceptible to external intervention. This fraught series of developments is often forgotten amid the turmoil caused by the Revolution's arrival in India. Next to the violence and confusion of the revolutionary movements in Chandernagor and Ile de France, the town experienced only a minor set of disruptions. More significant than the scale of Mahé's revolution, or the upheaval it generated, are the parallels between this event and the earlier moments in the comptoir's history. As was the case with the private trading controversies of the 1730s, the town's interactions with Haidar Ali in the 1760s, and the expansionist policies of Duprat in the 1770s, broader concerns within the French empire facilitated municipal reform and then pursuit of a fundamentally local political agenda.

\section{Conclusion}

As Mahé's history reminds, France's Indian settlements were not merely reactive places, alternatively obeying or defying the dictates handed down a distant metropolitan authority. Instead, these were dynamic spaces navigating between major shifts in French imperial policy and a recurring set of regional concerns. When approached from the perspective of an individual comptoir, the transitional moments in the history of French empire betray startling continuities - not only in patterns of municipal governance, but also in the way that major shifts in imperial policy were interpreted and shaped by agents on the ground.

Developments in Mahé challenge the traditional model of power in the imperial history of the old Regime. While crown ministers spoke of rigid hierarchy and undifferentiated sovereignty, colonial authority was open to constant negotiation, and the ideologies that infused France's imperial enterprise were reimagined by a variety of actors. If acknowledging this dynamic enriches our perspective on the French colonial project, it 
also qualifies our understanding of empire in the eighteenth century. For just as we must examine how a settlement like Mahé responded to broader changes in imperial ideology and policy, we must also ask how these developments were themselves shaped by the interests, obligations, and challenges unique to specific colonial spaces.

\section{NOTES}

1. Pierre-Antoine DUPRat, Voyage du Comte Duprat dans l'Inde, London, 1780, p. 2.

2. Philippe HAUDRÈRE, La Compagnie française des Indes au XVIIIème siècle, Paris, Indes Savantes, 2005, p. 225 and Catherine MANNING, Fortunes à faire: the French in Asian Trade, Aldershot, Variorum, 1996, p. 50.

3. This tendency is clearly evident in the scope of most historical studies of the French in India. Scholarship on the Company, for instance, tends to conclude with either the late 1740s, when the comptoirs began to engage more frequently in military activity, or the early 1760s, when the Treaty of Paris and an impending bankruptcy helped led to the end of Company rule. Histories of French military activity in India, by contrast, begin either in the 1750s or the 1760s. Kenneth Margerison offers one way of conceptualizing this shift, describing the French engagement with India in the early eighteenth century as one governed by the dictates of "political economy", and later interactions as guided by a policy of strategic military intervention hammered out by the Choiseul ministry. See Kenneth MARGERISON, "Commercial Liberty", Historical Reflections 35, Vol. 3, 2009 , p. 70. In either case, there is a clear gap, reinforced through historiographical practice, between different periods of colonial rule in French India during the eighteenth century-one that obscures the continuity in practices and ideologies of governance within individual comptoirs.

4. Kate MARSH, India in the French Imagination, London, Pickering \& Chatto, 2009, p. 4. For more on the impact of India on the development of public opinion in France see Indra MUKHOPADHYAY, "Imperial Ellipses: France, India, and the Critical Imagination", PhD diss., University of California, Los Angeles 63, 2008.

5. Susan DAWDY, Building the Devil's Empire: French Colonial New Orleans, Chicago, University of Chicago Press, 2008, p. 4-5. On the fissures within France's colonial project, and how these manifested themselves in matters of local governance in French India, see Danna AGMON, "An Uneasy Alliance: Traders, Missionaries, and Tamil Intermediaries in Eighteenth-Century France", PhD diss., University of Michigan, 2011, p. 5.

6. Alfred martineau, Les Origines de Mahé de Malabar, Paris, Champion, 1917, p. 3.

7. Simon DE LA FARELLE, Deux officiers français au XVIIIe siècle. Mémoires et correspondance du chevalier et du général de La Farelle, Paris, Berger-Levrault et Cie, 1896. p. 37.

8. S.P. SEN, The French in India, 1763-1816, Calcutta, Firma K.L. MUKHOPADHYAY, 1958, p. 95.

9. Ibid., p. 103.

10. Alfred MARTineau, Les Origines de Mahé de Malabar, op. cit., V.

11. Philippe HAUDRÈrE, La Compagnie française des Indes, op. cit., p. 238-241.

12. For the hierarchical organization of council rule see Henri WEBER, La Compagnie Française des Indes, 1604-1876, Paris, Arthur Rousseau, 190), p. 456-458.

13. On the flexible nature of corporate sovereignty see Philip STERN, The Company State: Corporate Sovereignty \& the Early Modern Foundations of the British Empire in India, Oxford, Oxford University 
Press, 2011, p. 13. Adam Clulow explores a similar pattern of rebranding in the Dutch East India Company's activities in Japan, suggesting that such activities were a common element of corporate administration across Asia, where Europeans encountered powerful political authorities and military forces, and gained access to territory through diplomacy rather than conquest. See Adam clulow, The Company and the Shogun: The Dutch Encounter with Tokugawa Japan, New York, Columbia University Press, 2014.

14. Catherine MANNING, Fortunes à faire, op. cit., p. 156-157. Figures prices from the pepper markets at Calicut, which grew slightly more dramatically than those of Mahé.

15. Alfred MARTINEAU, Les Origines de Mahé de Malabar, op. cit., VII.

16. For an in-depth study of Company trading practices see Catherine MANNING, Fortunes à faire, op. cit., p. 12-18. For the reorientation of the Indian market during the eighteenth century see Arvind SINHA, The Politics of Trade: Anglo-French Commerce on the Coromandel Coast, 1763-1793, New Delhi, Manohar, 2002, p. 30-38 and A. Das GUPTA, Malabar in Asian Trade, Cambridge, Cambridge University Press, 1967.

17. For this narrative of events see Simon DE LA FARELLE, Mémoires du Chevalier de la Farelle sur la Prise de Mahé, 1725, Paris, Challamal Ainé, 1887, p. 9-15.

18. Catherine MANNING, Fortunes à faire, op. cit., p. 157.

19. AN, 158 AP 14, Jacques d'Eprémesnil, Sur le Crédit de la Nation dans l'Inde (1755).

20. CCSC, iii, 41.

21. ANOM, $C^{2} 28$, Extrait du Registre Général des Délibérations de la Compagnie des Indes, du 14 Juillet 1739.

22. ANOM, $C^{2}$ 77-79, 2 April 1739; 15 April 1739.

23. ANOM, $C^{2} 77-79,30$ April 1739.

24. ANOM, $C^{2} 77-79,4$ May 1739; 6 May 1739.

25. 3 APC 1, Bayanor, Prince de Baragert aux directeurs et syndics de la très illustre et Royale Compagnie de France, 21 February 1740; Manning, Fortunes à Faire, 158.

26. CCSC, iii, 26 September 1739.

27. Ibid.

28. AN, 158 AP 14, Jacques d'Eprémesnil, Sur le Crédit de la Nation dans l'Inde (1755).

29. Ibid.

30. CCSC, iii, 30 September 1740 .

31. Ibid.

32. AN, 158 AP 14, Jacques d'Eprémesnil, Sur le Crédit de la Nation dans l'Inde (1755).

33. Ibid.

34. Alfred MARTINEAU, Introduction to Correspondance du Conseil Supérieur de Pondichéry et de la Compagnie, vol. I (1726-1730), p. 14.

35. Catherine MANNING, Fortunes à faire, op. cit., p. 156.

36. Two major questions are often asked regarding to this development: 1) Did Dupleix's emphasis on military activity constitute a dramatic change in French imperial policy? 2) Did European aggression signal the end of indigenous power on the subcontinent? For the theoretical implications of these aggressive policies within French political economy John SHOvLIN, "War and Peace: Trade, International Competition, and Political Economy," in Philip STERN and Carl WENNERLIND, eds., Mercantilism Reimagined: Political Economy in Early Modern Britain and its Empire, (Oxford: Oxford University Press, 2014, p. 306-313. For the ways in which Dupleix's policies elaborated upon and reaffirmed indigenous political practices see P.J. MARSHALL, ed., The Eighteenth Century in India: Evolution or Revolution?, New Delhi: Oxford University Press, 2003, p. 26. 37. ANOM, 25 DFC 93, Mémoire de M. Dupleix concernant le commerce de l'Inde; Joseph DUPLEIX, Mémoire pour le sieur Dupleix, contre la Compagnie des Indes: avec les pièces justificatives (1759). 
38. For this satirical eulogy, see BNA MS 6544, Prospectus de la pompe funèbre de feue très haute, très puissante, très excellente princesse, Madame la Compagnie des Indes, souveraine de la presqu'isle de l'Inde et cy-devant des Iles de France, de Bourbon et du port de Lorient (1769). For the conflicts accompanying the company's collapse, see Kenneth MARGERISON, “The Shareholders' Revolt at the Compagnie des Indes: Commerce and Political Culture in Old Regime France”, French History 20, no. 1 (2006), p. 25-51.

39. S. P. SEN, The French in India, op. cit., p. 93.

40. BNF, NAF 9031, Calicut to Pondichéry, 26 September 1765.

41. Ibid.

42. BNF, NAF 9031, Calicut to Pondichéry, 30 October 1765.

43. Jean Law DE LAURISTON, Mémoires sur les diverses nations établies dans l'Inde (1767), p. 16-17.

44. For a good summary of this historiographical division, see Kate MARSH, India in the French Imagination, op. cit., p. 19.

45. On the improvisational nature of French geo-political strategy in India, see Sudipta DAS, Myths and Realities of French Imperialism in India, 1763-1783, New York, P. Lang, 1992.

46. For a good summary of French relations with Haidar Ali, see Maya JASANOFF, Edge of Empire: Lives, Cultures, and Conquest in the East, 1750-1850, New York, Vintage Books, 2006, p. 154-157.

47. BNF, NAF 9031, Calicut to Pondichéry, 26 September 1765.

48. BNF, NAF 9031, Mahé to Pondichéry, 19 November 1766.

49. BNF, NAF 9031, Mahé to Pondichéry, 21 January 1766.

50. BNF, NAF 9031, Mahé to Pondichéry, 13 May 1766.

51. S. P. SEN, The French in India, op. cit., p. 99.

52. Pierre-Antoine DUPRAT, Voyage du Comte Duprat dans l'Inde, op. cit., p. 3-4.

53. On the restructuring of council authority see Gnanou DIAGOU, Arrêts du Conseil Supérieur de Pondichéry, I, Pondichéry, Imprimerie de la mission, 1935, X-XII.

54. RCP, ECD 150, Mahé to Pondichéry, 17 August 1773.

55. Pierre-Antoine DUPRAT, Voyage du Comte Duprat dans l'Inde, op. cit., p. 4-5.

56. Ibid.,

57. Ibid., p. 6-7.

58. Ibid., p. 47-48.

59. Ibid., p. 50.

60. S. P. SEN, The French in India, op. cit., p. 97.

61. Ibid., p. 99.

62. Ibid., p. 102.

63. Dupleix, in particular, has inspired a variety of scholarly treatments, much of it aimed at understanding whether or not his policies signaled a dramatic shift in French imperial policy and whether the British - especially Clive - then emulated his methods to greater success. See Marc CHASSAIGNe, Bussy en Inde, Chartres, Marchand, 1976; Henry Dowdwell, Dupleix and Clive: The Beginning of Empire, London, Cass, 1967; Rose VINCENT, "Zenith in Pondicherry", in The French in India: From Diamond Traders to Sanskrit Scholars, Rose Vincent, ed, Bombay, Popular Prakashan, 1990; Alfred MARTINEAU, Dupleix et l'Inde Francaise: 1749-1754, Paris, Société d'Editions Géographiques, Maritimes et Coloniales, 1928.

64. RCP, ECD 150, Paris to Pondichéry, 1 March 1789.

65. Ibid.

66. Ibid.

67. On Necker's contribution as a Company shareholder see Kenneth MARGERISON, "The Shareholders' Revolt at the Compagnie des Indes: Commerce and Political Culture in Old Regime France", op. cit. and Anoush TERJANIAN, Commerce and its Discontents in Eighteenth-Century French Political Thought, Cambridge, Cambridge University Press, 2013 p. 147-161. 
68. For Montigny's diplomatic efforts, see RCP, ECD 41, Copie d'une lettre de Monsieur Montigny au sujet de la paix avec toutes les puissances du Dékan, 1783. For the French war in India during the American Revolutionary War, see George MALLESON, Les dernières luttes des français dans l'Inde et sur l'Océan Indien, Pondichéry, Imprimerie du Gouvernement, 1911.

69. S. P. SEN, The French in India, op. cit., p. 473.

70. Ibid.

71. For more on the precarious finances of Calonne's Company, see John SHovLIN, The Political Economy of Virtue: Luxury, Patriotism, and the Origins of the French Revolution, Ithaca, NY, Cornell University Press, 2006, p. 157-159.

72. BNF NAF 9373, De Canaple to Conway, 10 September 1789.

73. On the transformation of Mahé's government's conseil, see Gnanou DIAGOU, Arrêts du Conseil Superieur de Pondichéry, op. cit., XIII; on the limits set on corporate administration under the Calonne Company see Henri WEBER, La Compagnie Française des Indes, op. cit.

74. For more on this dynamic within the French colonies see Laurent DUBOIs, Avengers of the New World, Cambridge, MA, Harvard University Press, 2004, especially chapter 4.

75. See Paul CHENEY, Revolutionary Commerce: Globalization and the French Monarchy, Cambridge, MA, Harvard University Press, 2010, especially chapter 7.

76. Laurent DUBoIs, A Colony of Citizens: Revolution and Slave Emancipation in the French Caribbean, 1787-1804, Chapel Hill, NC, University of North Carolina Press, 2004.

77. BNF NAF 9373, Le Tellier to de Fresne, 10 May 1790.

78. BNF NAF, 9373, Le Teller to de Fresne, 5 April 1791.

79. Ibid.

80. Marguerite V. LABERNADIE, La Révolution et les établissements francais dans l'Inde, d'après les archives de Pondichéry, des notes et des correspondances inédites, p. 320. See also S. P. SEN, The French in India, p. 476-278.

81. BNF NAF 9373, Boyer to the Colonial Assembly of Mahé, 15 April 1791.

82. This saga was reported a month after the fact in Le Tellier's correspondence with Pondichéry. See BNF NAF 9373, Le Tellier to de Fresne, 4 July 1791; Le Tellier to de Fresne, 20 July 1791.

83. Langlade quoted in Marguerite V. LABERNADIE, La Révolution et les établissements français dans l'Inde, op. cit., p. 323.

84. BNF NAF 9373, "Copies de toutes les pièces justificatives", 22 May 1792.

85. BNF NAF 9373, Procès-verbal de l'Assemblé nationale de Mahé, 24 June 1792.

86. BNF NAF 9373, Larcher à l'Assemblée nationale de Mahé, 8 July 1792.

87. BNF NAF 9373, Langlade to de Fresne, 9 July 1792.

88. BNF NAF 9373, Langlade and Menesse, 5 October 1792.

89. For details of this affair see the October-November correspondence between Larcher and Cornwallis. BNF NAF 9373, Larcher to Cornwallis, 24 October 1791, 1 November 1791, 3 November 1791, 4 November 1791, 5 November 1791; Cornwallis to Larcher, 3 November 1791, 5 November 1791.

90. S. P. SEN, The French in India, op. cit., p. 481. 


\section{ABSTRACTS}

This article explores Mahé's interconnected experiences as both a semi-autonomous municipal government and a subordinate territory within France's overseas empire. A small, often neglected outpost on the southwestern coast of India, Mahé carved out a distinct regional identity over the course of the eighteenth century. Following the town's history from its establishment in 1725 to its capture by the British in 1793, I examine the striking continuities within its municipal political culture, even in the face of ongoing changes to French colonial policy in Versailles. This article highlights the role of supposedly marginal spaces in the development of imperial ideology, revealing how local politics infused and often repurposed France's colonial project in the eighteenth century.

Cet article explore les histoires interconnectées de Mahé en tant que ville semi-autonome du gouvernement municipal et en tant que territoire subordonné de l'empire français d'outre-mer. Mahé était une petite colonie sur la côte sud ouest de l'Inde. Elle développa une identité régionale distincte au cours du XVIII ${ }^{\text {ème }}$ siècle. En examinant l'histoire de cette ville de sa fondation en 1725, jusqu'à sa prise par les Anglais en 1793, cet article illumine des continuités frappantes dans sa culture politique, alors que la politique coloniale de la France changeait rapidement à Versailles. Cet article souligne l'influence des lieux marginaux dans la construction de l'idéologie impériale, en révélant la manière dont la politique locale infusa et s'appropria le projet colonial de la France au XVIII ${ }^{\mathrm{ème}}$ siècle.

\section{INDEX}

Mots-clés: Mahé, la Côte de Malabar, la Compagnie des Indes, Conseil Provincial Keywords: Mahé, Malabar Coast, Compagnie des Indes, Provincial Council

\section{AUTHOR}

\section{GREGORY T. MOLE}

The University of North Carolina at Chapel Hill 